\title{
Impacts of Derived Tin Mining Activities on Landuse/Landcover in Bukuru, Plateau State, Nigeria
}

\author{
Jiya Solomon Ndace ${ }^{1} \&$ Musa Haruna Danladi ${ }^{2}$ \\ ${ }^{1}$ Department of Geography and Geology, Ibrahim Badamasi Babangida University, Lapai, Niger State \\ 2 Urban and Regional Planning Department, Federal University of Technology, Minna, Niger State \\ Correspondence: Musa Haruna Danladi, Urban and Regional Planning Department, Federal University of \\ Technology, Minna, Niger State. E-mail:musharry@yahoo.com, musaharunad@futminna.edu.ng
}

Received: January 30, 2012 Accepted: March 30, 2012 Online Published: May 1, 2012

doi:10.5539/jsd.v5n5p90

URL: http://dx.doi.org/10.5539/jsd.v5n5p90

\begin{abstract}
Tin mining activity which was a predominant activity around the Jos Plateau has caused considerable erosion damages to landuse/landcover. Uncontrolled effects through monitored activities do not protect future environmental security. This paper therefore, assesses impact of derived mining activities on landuse/ landcover in Bukuru area in Jos south of Nigeria to determine the extent of degraded mine lands. A time series analysis of Landsat MSS satellite image November 1975, Landsat TM satellite image acquired in 1989, and Landsat ETM acquired October 2005 of the study area were used. Landuse/ landcover were classified from the images using a hybrid manual and spectral based approach. The result shows that out of the 1,574.13sq.km total size of the study area, the degraded area/land, Built-up area, and water bodies increased by $24.58 \%, 18.51 \%$ and $7.57 \%$ respectively. Whereas Arable land (farm and grazing land) and forest reserve has decreased by $106.60 \mathrm{sq} . \mathrm{km}$ $(14.16 \%)$, and 264.89 sq. (35.18\%) respectively. It was recommended that comprehensive mitigation studies against these damages should be performed, and regular inspections should be executed to keep these activities of tin mining under control. Modern technologies should be used to obtain more effective results from these studies.
\end{abstract}

Keywords: landuse/landcover change, urban ecological degradation, deforestation, geospatial analysis

\section{Introduction}

Human spatial curiosity, systematic field study and quality management of available natural resources are widely recognized as essential components of planning and developmental process in the contemporary society. Mining activity which was a predominant activity around the Jos Plateau has evident from the fact that the southern part of the area is surrounded by many mining and pilot ponds. Mining and processing has led to socio-economic and infrastructural development of the area, with major negative impacts on biophysical and hydrological environments. Similar negative impacts are widespread in most other small-scale, largely illegal mining areas in Nigeria. The importance of the environment to sustainable development in any society is not in doubt. There must be a healthy, rich and adequately protected environment in order to have a healthy, prosperous society. The environment provides the foundation for all development efforts in the country. Its close linkages with the major sectors of the economy are readily discernible from the fact that agricultural productivity and subsequently food security cannot be guaranteed in a degraded environment because of declining soil fertility due to mining.

Tin mining and processing constitute a source of pollution to the environment (Adiuku et al., 1991) because with tin the accessory minerals associated are harmful even to human beings and animals at low concentrations. The mining of tin facilitates the release of radioactive minerals from the host rocks into the environment.

The degradation of the mining region is often thought of in terms of the extent of land coverage affected by mining activities. Research has shown that the total land affected by actual mining is not more than $3 \%$ of the Jos Plateau (Sumaila, 1989).

The impacts of mining activities on the study area are immense. Uncontrolled effects through monitored activities do not protect future environmental security. Erosion by water is the most common form of soil degradation, causing loss of soil nutrients, organic matter and damage to soil physical properties and standing crops. A prudent society conserves her mineral deposits by monitoring through proper planning and mining in such a manner as to maximize the benefits. 
Tin mining activities which have caused considerable erosion damages to lands arising from active gully equal to $7,240 \mathrm{~km}$ in length (Sumaila, 1993). Apart from tin mining, it is obvious that such human activities like construction of highways, rail roads, pipelines, airport, industrial sites, sanitary landfills, dam reservoirs, timber harvesting, bush burning and grazing have potential and adverse effects on the environment. Environmental degradation is a very serious issue. To ignore the environment, is to ignore our humanity and surrender its race that is entirely dependent on it. There is the need to manage the ecosystem responsibly so that those coming after will not have to complain, worry or curse their ancestors.

Some of the biophysical effects of these human activities on the environment include:

(i) Interruptions and other changes in natural conditions that cause ponds fluctuations of groundwater level, alterations to stream flow characteristics, and soil Erosion and Siltation.

(ii) Changes in water turbidity, suspended load and increase in temperature.

(iii) Increase in chemical pollutants such as heavy metals, salt and insecticides.

(iv) Changes in vegetation caused by site clearing and alterations of the systems in the natural region.

The influxes of operators without adequate monitoring of production and documentation do not augur well for conservation of minerals and land use systems. The operators such as George R. Nicholas, Col. H. W. Laws, The Royal Niger Company, Bisichi Tin Company, Kaduna Prospectors, Amalgamated Tin Miners, Gold and Base metal Nigeria Limited, United Areas of Nigeria Limited and Jantar Nigeria Company are in different categories: the public liability companies, private liability companies, firms with registered names and private operators.

The tin mining landscape of the Jos Plateau is characterized by mined ponds, pilot ponds, reservoirs, mine dumps and mounds. These man-made features have not been considered as resources, but they present great potentials for development of water resources, irrigation agriculture, recreation and tourism and construction work. The mine dumps and tailings also have resource value. Spoil materials from them have been used for road construction and maintenance works particularly for road fill.

Since the Plateau mine-lands posses a great deal of potential for development. In these mine ponds, and reservoirs, landuse planning for the region should consider the balance between the needs of the population for land and water resources in reclamation matters so as to contribute functionally and socially.

The thesis therefore, assess some impact of mining activities on vegetation and landuse in Bukuru area in Jos south of Nigeria to determine the extent of degraded mine lands in order to make recommendation to effectively manage the existing degraded environment.

\section{Background}

For many years past, Jos Plateau has witnessed incessant soil destruction by mining operations. Around Bukuru mine tailings, neglected excavations and unfilled sample pits have an indelible disfiguration of a once rich and beautiful region. The displaced persons of the Jos Plateau mining region together with migrant workers who have become jobless as a result of considerable reduction in mining activities and population growth have continued to exert pressure on the largely reduced useable agricultural lands (Adepetu, 1986), and caused series of land conflicts which in turn metamorphosed into incessant ethno-communal and tribal clatters, and religion crises in this areas (Musa, 2010).

Lands are mined extensively in the study area and it may take not less than 15 years to be reclaimed. Despite the existing laws, little or no attention is paid to reclamation of the derelict mining ponds. However, the devastating effects of erosion caused by mining activities, coupled with the large number of abandoned lease is also attributed to large number of migrants who cannot claim ownership over the land.

An important element in the present and future programs for assessing the land resources is the availability of a monitoring system to determine the resources stock, rate in use as well as monitoring the environmental impact on the use of the resource (Tin). The continuous mining activities and clearing of woodland for cultivation, call for the need to up-date the information on landuse on the Jos Plateau to reduce environmental problem in the area.

The paper therefore, assesses the biophysical impacts of tin mining activities in the Jos south area, Bukuru plateau state in order to generate useful information necessary for the management of the degraded land for sustainable development. 


\section{Tin Mining Zones in Jos}

The mining region today can be recognized as one of the several ecological sub-regions of the Jos Plateau. According to Ajaegbu (1985), the delimitation of the mining region is based on the area extent of mining activities, past and present, the distribution of identifiable mining landscape features and mining settlement (both in existence or those that have once existed). The spread of the traceable past, abandoned and present stream valleys of alluvial deposit of tin and associated minerals in the mining region can be delineated into three mining zones:

a. The first zone consists of the congested Jos-Naraguta South-Eastern Bassa mining zone. This is the earliest area of tin mining activities on the Jos Plateau. As a result of increased population, urbanization and intense landuse competition, the zone was declared by the State and Federal government a "congested area" and further mining barred (Ajaegbu, 1985).

b. The second is Bukuru-Rayfield, Sabon- Gida mining zone which is characterized by mounds of mine tips. The main features here are mining ponds, abandoned mining sites and partly deserted mining settlements with several pilot ponds (Figure 1).

c. The third zone comprises the Barkin-Ladi, Bisiahi, Ropp-Dorowa mining area. This zone, like zone (b) above, is a contemporary one which is characterized by the use of heavy and deep mining equipment.

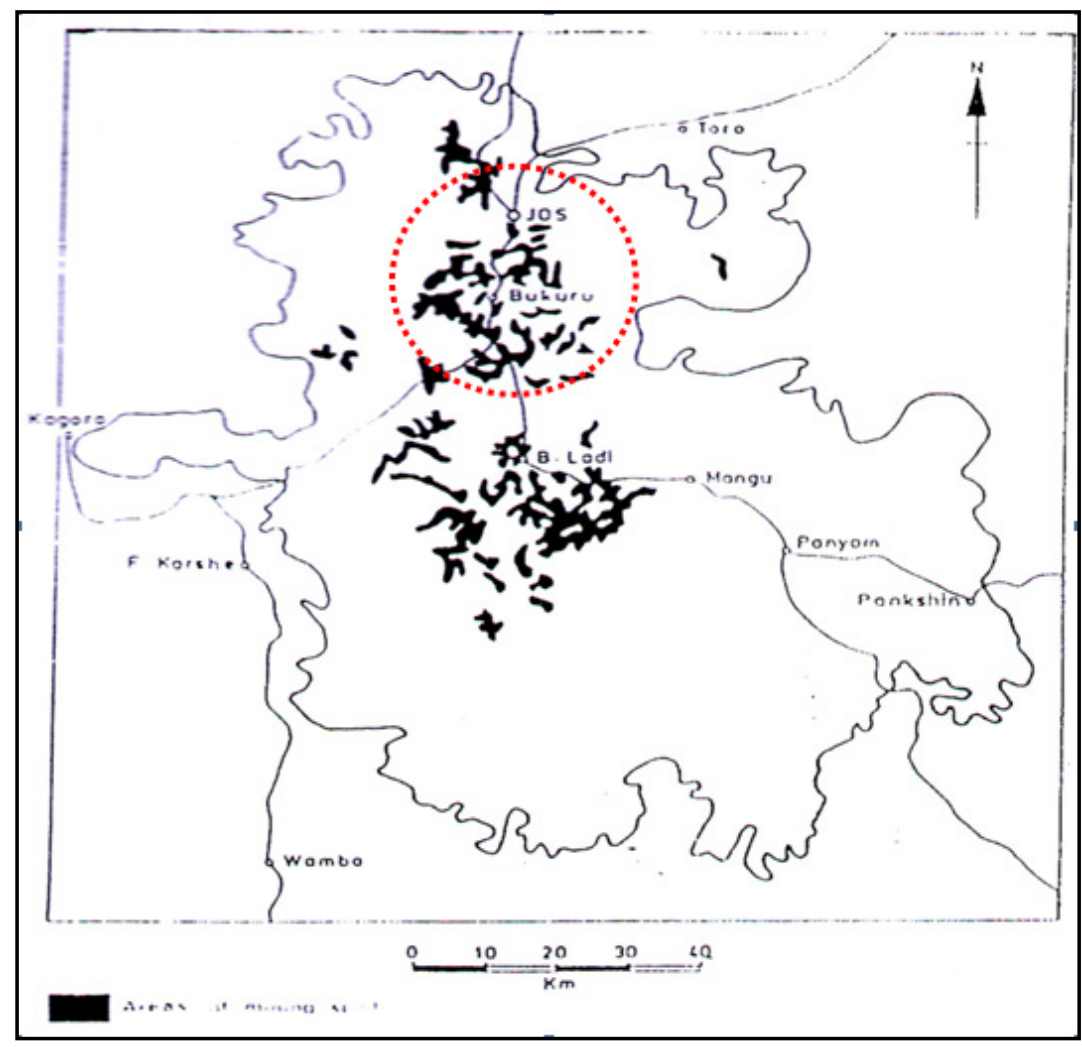

Figure 1. The Mining Areas in Bukuru- Jos

Quite clearly, the landuse and management problems and strategies differ from zone to zone. For example in zone one, heavy mining activities have ceased and the degraded lands are undergoing reclamation and restoration while in zone two, mining activities is still viable with some efforts in reclamation and restoration. In zone three, there is active mining activities through the use of modern machines are on.

Tin mining industry had been dominant in the Jos plateau region at the expense or neglect of several other sectors of economic pursuit which could also be very profitable. Two of such socio-economic pursuits are fadama farming and tourism and leisure.

By the year 1902 when the bulk of Nigerian tin was found in Jos Plateau; the mining industry provided employment opportunities and most importantly the mineral exploitation provided a good source of revenue. The 
mining of such a resource provide opportunities for communities in the area to enjoy certain benefits. These include water, electricity, good and accessible roads, hospitals markets etc. These amenities were provided for the company workers but the communities invariably benefited from them.

The mining ponds are intensively used for water supply, fish farming and irrigation. But in spite of these enumerated advantages, mining activities on the Jos Plateau have left a terrible land destruction in which life exist. The miners have just one goal to dig out tin no matter what happens to the land and life in the process. The initial green vegetation (Plate 1) of the region had given way to brown soils which lack fertility.

According to Ajaegbu (1985), the country side has been greatly disfigured by heaps of compacted tips often bare or with very scanty vegetation, mining spoils of slurry and tin failing spread over wide areas; earth banks of unconsolidated steep paddock mounds of loose sand, clayey soils, deep mining pits, neglected mining excavations. There are also evidences of soil destruction, soil loss and lower land capability (soil) as a result of mining activities. Food crops such as potatoes, carrots, maize, onions, tomatoes, and vegetables grown in tin mining areas are smaller in size and different in taste compared to those brought in from other areas such as Mangu, Bassa, Miango and other producing places.

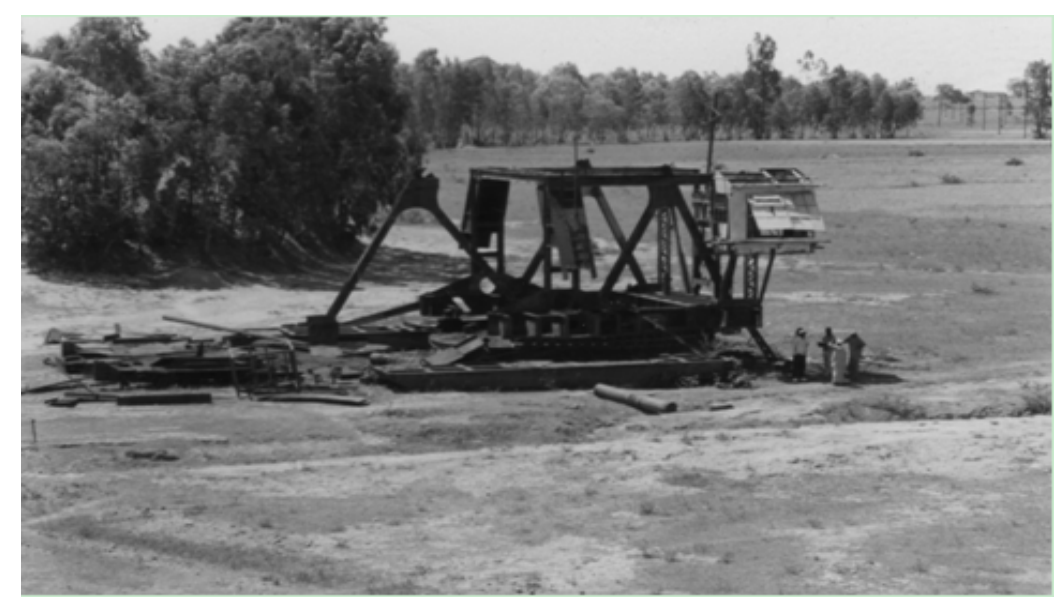

Plate 1. Typical forest and woodland around an abandon mining site

\section{Study Area}

The Jos Plateau lies in the middle belt of Nigeria. It is approximately $104 \mathrm{~km}$ ( 65 miles) from North to South, and $80 \mathrm{~km}$ (50 miles) from east to West covering an area of $8,600 \mathrm{~km}^{2}$. The Jos Plateau has steep escarpment edges with a descent of about $600 \mathrm{~m}$ to the surrounding plains. The Southern part of Jos Plateau is in the Benue Lowlands extending towards the River Benue flood plain. Jos Plateau is situated between latitudes $10^{\circ} 11^{\prime} \mathrm{N}$ and $8^{\circ} 55^{\prime} \mathrm{N}$ and longitude $8^{\circ} 21^{\prime} \mathrm{E}$ and $9^{\circ} 30^{\prime} \mathrm{E}$ (Figure 2). The study area (Bukuru-Jos) lies between latitudes $8^{\circ} 50^{\prime} \mathrm{N}$ and $9^{\circ} 00^{\prime} \mathrm{N}$ and longitude $9^{\circ} 45^{\prime} \mathrm{E}$ and $9^{\circ} 50^{\prime} \mathrm{E}$. It is about $8 \mathrm{~km}$ away from Jos town and has total land area of 22 $\mathrm{km}^{2}$; it was formally dominated by mining activities in areas such as Maiadiko, Gold and base settlements, etc. It has an average elevation of about 1,150 metres above mean sea level and the highest peak some $20 \mathrm{~km}$ eastwards from Jos-shere hill, rising to 1777 metres above mean sea level (Morgan, 1979). 


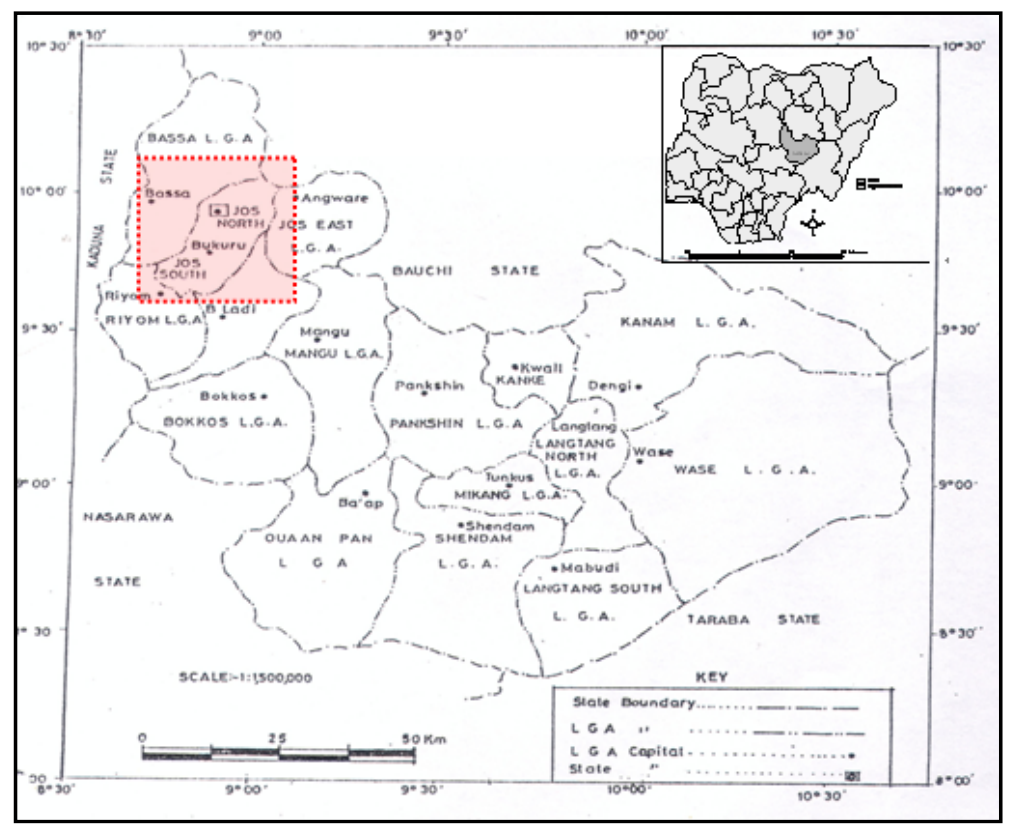

Figure 2. The Location of Bukuru, Plateau State

\section{Materials and Methods}

\subsection{Analysis of Remote Sensing Data (Image Processing)}

A time series Landsat MSS satellite image November 1975, Landsat TM satellite image acquired in 1989, and Landsat ETM acquired October 2005 of the study area were used. The imageries were obtained from the National Centre for Remote Sensing, Jos. They were geometrically registered to the 1:12,500 scale topographic maps of the area. Landuse and landcover was classified from the images using a hybrid manual and spectral based approach. Data for ground referencing for the classification came from several sources that included extensive field observations, and 1991 aerial photographs of the area. The landuse and landcover nomenclature was based on six (6) criteria; arable land, water body, degraded areas, forest (woody tree density), rock/hill and built-up areas. The results were then analysed using post classification differencing (Lillesand \& Kiefer, 2000).

\section{Results and Discussion}

\subsection{Landuse/Landcover Distribution of 1975 Mining Period}

The Landuse/landcover category for study area in 1975 was assessed (Figure 3). The result shows that Water body in 1975 constitute the lowest of the class with just $2 \%$ of the total classes, while the built-up in 1975 constitute the lowest of the class with just $6.31 \%$ of the total classes. The arable land (farmland) occupying $49.52 \%$ of the total classes. 

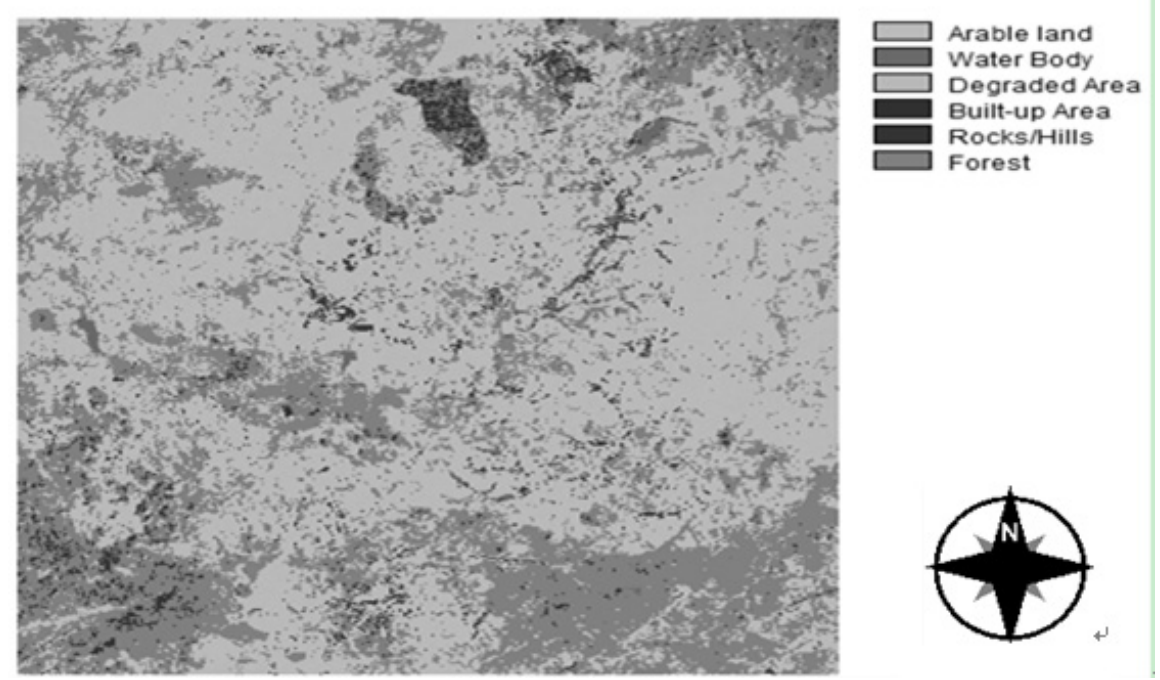

Figure 3. The landuse pattern and the extent of Mining Degradation from LandSat MSS, 1975

The classified image of 1975 mining period also revealed that the degraded area and Forest lands. The degraded area occupied 213.72 sq.km of the total area (1574.13sq.km) representing 13.57\% (Table 1). Forest land (woody tree density) is predominantly found in the eastern and western part of the study area, and sparsely intersperses with other landcover and occupied $26.74 \%$. The landcover is seen mostly around the water bodies especially the drainage channels of Rivers, wetland and ponds.

Table 1. Spatial extent of landuse/landcover change in 1975 and 1986

\begin{tabular}{ccccc}
\hline Land use Class & 1975. Area in Sq.km & $\begin{array}{c}\text { Percentage coverage } \\
\mathbf{( \% )}\end{array}$ & $\begin{array}{c}\text { 1986. Area in } \\
\text { Sq.km }\end{array}$ & $\begin{array}{c}\text { Percentage } \\
\text { coverage } \\
(\%)\end{array}$ \\
\hline Arable land & 779.64 & 49.52 & 549.47 & 34.9 \\
Water Body & 31.52 & 2 & 59.09 & 3.78 \\
Degraded Area & 213.72 & 13.57 & 368.22 & 23.39 \\
Built-up Area & 99.35 & 6.31 & 168.41 & 10.69 \\
Rocks/Hills & 29.38 & 1.86 & 29.38 & 1.86 \\
Forest & 420.52 & 26.74 & 399.56 & 25.38 \\
\hline Total & $\mathbf{1 5 7 4 . 1 3}$ & $\mathbf{1 0 0}$ & $\mathbf{1 5 7 4 . 1 3}$ & $\mathbf{1 0 0}$ \\
\hline
\end{tabular}

\subsection{Landuse/Landcover Distribution of 1986 Mining Period}

The classified map of Mining activity in 1986 (Figure 4) shows a wide spread of degraded area, especially in the centre and around the eastern part of the map. Results (Table 1) shows that there is a significant decrease in the existence of arable land and forest areas, covering 549.47 sq.km (34.9\%) and 399.56sq.km (25.38\%) of the total area respectively. However, the degraded areas and the water bodies are in the increase. The increase in the degradation could be attributed to proliferating mining activity in the area. This result also revealed an increase in the degraded area and water bodies, covering 368.22sq.km (23.39\%) and 59.09sq.km (3.78\%) respectively. The increase in surface water is as a result of water found in an abandon mining ponds spread around the area. This phenomenon indicates a prevalence of intensive mining and cultivation practices. This result also shows that $10.69 \%$ of the study area constitutes the built-up area (physical development), covering 168.41 sq.km of total land coverage. 

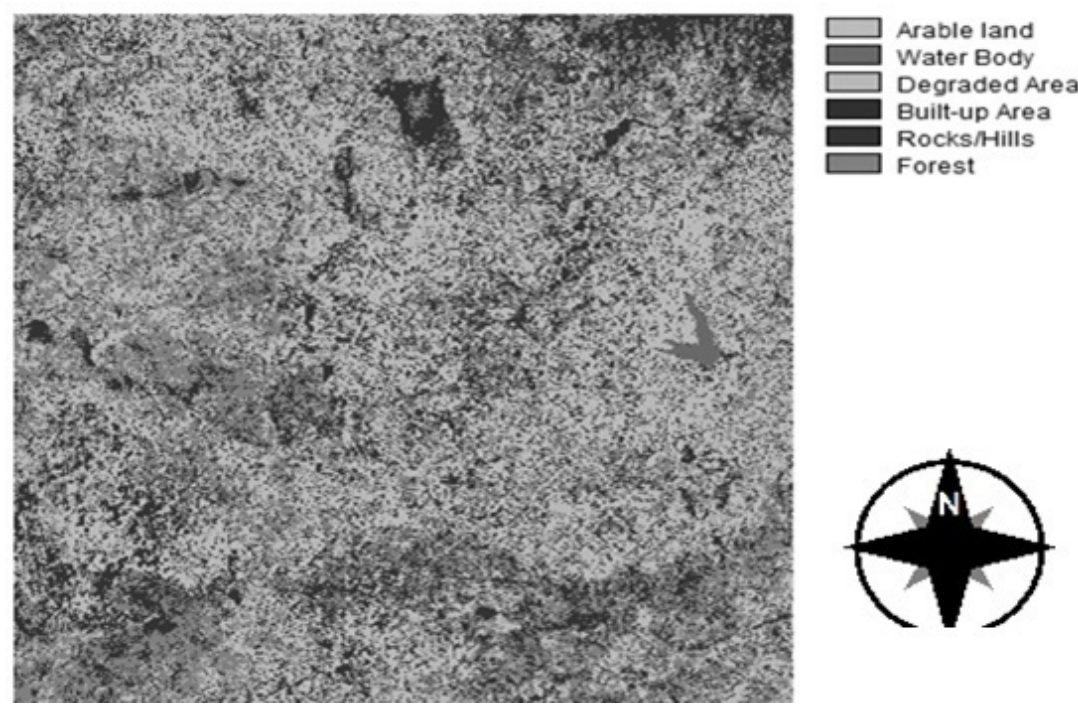

Figure 4. The landuse pattern and the extent of Mining Degradation from LandSat TM, 1986

\subsection{Magnitude of Change in Landuse/Landcover Resulting from Mining: 1975 -1986}

The study reveals a high amount of change in Landuse/Landcover in Jos-Plateau during the 11 years period between the year of 1975 and 2086 as a result of surface mining activities (Figure 3 \& 4). It was found that the area of degradation (from tin mining) covered $213.72 \mathrm{Km}^{2}$ of land in the year of 1975; this value has notably increased to $368.22 \mathrm{Km}^{2}$ in 1986 . The area covered by forest decreased to $399.56 \mathrm{Km}^{2}$ from $420.52 \mathrm{Km}^{2}$ in same period. This implies that the magnitude of forest area decreases by about $20.96 \mathrm{Km}^{2}$ representing $4.17 \%$ of the total land coverage between the 1975 and 1986 (Table 2).

Table 2. Magnitudes of change in land use between 1975 and 1986

\begin{tabular}{ccccccccc}
\hline $\begin{array}{c}\text { Land use } \\
\text { Class }\end{array}$ & $\begin{array}{c}\mathbf{1 9 7 5} \text { Area } \\
\text { ( Sq.km) }\end{array}$ & $\mathbf{\%}$ & $\begin{array}{c}\mathbf{1 9 8 6} \text { Area } \\
\mathbf{( S q . k m )}\end{array}$ & $\mathbf{\%}$ & $\begin{array}{c}\text { Magnitude } \\
\text { of change } \\
\text { ( Sq.km) }\end{array}$ & \% & Remarks \\
\hline Arable land & 779.64 & 49.52 & 549.47 & 34.9 & -230.17 & 45.82 & Loss \\
Water Body & 31.52 & 2 & 59.09 & 3.78 & 27.57 & 5.48 & Gain \\
Degraded Area & 213.72 & 13.57 & 368.22 & 23.39 & 154.50 & 30.75 & Gain \\
Built-up Area & 99.35 & 6.31 & 168.41 & 10.69 & 69.06 & 13.78 & Gain \\
Rocks/Hills & 29.38 & 1.86 & 29.38 & 1.86 & 00.00 & 00.00 & NA \\
Forest & 420.52 & 26.74 & 399.56 & 25.38 & -20.96 & 4.17 & Loss \\
\hline Total & $\mathbf{1 5 7 4 . 1 3}$ & $\mathbf{1 0 0}$ & $\mathbf{1 5 7 4 . 1 3}$ & $\mathbf{1 0 0}$ & $\mathbf{5 0 2 . 2 6}$ & $\mathbf{1 0 0}$ & \\
\hline
\end{tabular}

However, the area covered by an arable land was 779.64 sq.km in 1975; this value decreased to $549.47 \mathrm{sq} . \mathrm{km}$ in 1986. The area of water body was 31.52 sq.km in 1975 , and this increased to 59.09 sq.km in 1986. During the field observation it was seen that the change in the water area is derived from the mining activities as a result of the large mining pools filled with water. The result also reveals a significant destruction to forests in the study area as a result of the mining activities. The expansion of mining quarries drastically resulted in deforestations. The magnitudes of degraded area between the given periods have expanded by $154.50 \mathrm{sq} . \mathrm{km}(30.75 \%)$.

\subsection{Landuse/Landcover Distribution of 2005 Mining Period}

Results in Figure 5 and Table 3, have shown changes in the distribution of Landuse/Landcover in the area. Arable land covers $673.04 \mathrm{sq} . \mathrm{km}(42.75 \%)$. The increase in arable land in this period is resulted from extensive farming and grazing practices among the inhabitants. 
Water bodies are on the increase covering 88.59 sq. $\mathrm{km}(5.65 \%)$ of the total land coverage. This increase was as a result of rainfall and adverse effect of erosion from intensive mining activities. There is also an increase in Built-up area, covering 228.69Sq.km (14.55\%) resulting from increased urbanization. There is a considerable appearance of degraded surfaces/areas mostly around water bodies, farmlands areas. This class covered an aerial extent of 398.8sq.km (25.33\%). The expanse of degraded areas resulted from soil erosion, and practices such as over grazing and intensive cultivation and bush burning. The forest land declined covering $155.63 \mathrm{sq} . \mathrm{km}$ of land (9.88\%) compared to 399.56 sq.km (26.28\%) of total land coverage in 1986.

Table 3. Aerial coverage and percentage of landuse/landcover in 1986 and 2005

\begin{tabular}{ccccc}
\hline Landuse Class & $\begin{array}{c}\text { 1986 Area in } \\
\text { Sq.km }\end{array}$ & $\begin{array}{c}\text { Percentage coverage } \\
\mathbf{( \% )}\end{array}$ & 2005 Area in Sq.km & $\begin{array}{c}\text { Percentage coverage } \\
\mathbf{( \% )}\end{array}$ \\
\hline Arable land & 549.47 & 34.9 & 673.04 & 42.75 \\
Water Body & 59.09 & 3.75 & 88.59 & 5.65 \\
Degraded Area & 368.22 & 23.35 & 398.8 & 25.33 \\
Built-up Area & 168.41 & 10.69 & 228.69 & 14.55 \\
Rocks/Hills & 29.38 & 1.84 & 29.38 & 1.84 \\
Forest & 399.56 & 26.28 & 155.63 & 9.88 \\
\hline Total & $\mathbf{1 5 7 4 . 1 3}$ & $\mathbf{1 0 0}$ & $\mathbf{1 5 7 4 . 1 3}$ & $\mathbf{1 0 0}$ \\
\hline
\end{tabular}

\subsection{Magnitude of Change in Landuse/Landcover Resulting from Mining: 1986 - 2005}

From the presentation in Figure 5 and Table 4, changes were noticed in the landuse pattern between 1986 and 2005. The magnitude of change (Table 4) shows a substantial gain in Arable land by $123.67 \mathrm{sq} . \mathrm{km}$ (25.34\%). Such a gain can be attributed to a possible occupational change especially from mining to extensive farming and grazing due to the decline in mining activities in recent time. The result also shows a drastic loss in Forest reserve by $243.93 \mathrm{sq} . \mathrm{km}(49.98 \%)$. This development implies a possible loss of land to arable land which increased by $123.67 \mathrm{sq} . \mathrm{km}$. It is also observed that water bodies have indicated a considerable increase by 29.50sq.km representing $6.04 \%$.

The degraded area has also indicated a gain by $30.58 \mathrm{sq} . \mathrm{km}$ representing $6.26 \%$. This development implies possible loss of land for farming and grazing activities. The phenomenon also implies a considerable economic loss on farming activities since large portion of arable land are degraded paving way to further deforestation in quest for farm and graze land. However, built up area has further experienced a noticeable increase by $12.38 \%$ covering $60.28 \mathrm{sq} . \mathrm{km}$ of total land coverage. This phenomenon can be attributed to continuous urbanisation with significant increase in human population. The impacts of mining activities on the study area are immense. Uncontrolled and abandoned mining ditch continuously expand and encroaches adjoining physical properties (Plate 2) causing threat to the environmental and insecurity to lives and properties.

Table 4. Magnitudes of change in land use between 1986 and 2005

\begin{tabular}{ccccccccc}
\hline Land use Class & $\begin{array}{c}\text { 1986 Area } \\
\text { (Sq.km) }\end{array}$ & $\mathbf{\%}$ & $\begin{array}{c}\mathbf{2 0 0 5} \text { Area } \\
\text { (Sq.km) }\end{array}$ & \% & $\begin{array}{c}\text { Magnitude } \\
\text { of change } \\
\text { ( Sq.km) }\end{array}$ & \% & Remarks \\
\hline Arable land & 549.47 & 34.9 & 673.04 & 42.75 & 123.67 & 25.34 & Gain \\
Water Body & 59.09 & 3.78 & 88.59 & 5.65 & 29.50 & 6.04 & Gain \\
Degraded Area & 368.22 & 23.39 & 398.8 & 25.33 & 30.58 & 6.26 & Gain \\
Built-up Area & 168.41 & 10.69 & 228.69 & 14.55 & 60.28 & 12.38 & Gain \\
Rocks/Hills & 29.38 & 1.86 & 29.38 & 1.84 & 00.00 & 00.00 & NA \\
Forest & 399.56 & 25.38 & 155.63 & 9.88 & 243.93 & 49.98 & Loss \\
\hline Total & $\mathbf{1 5 7 4 . 1 3}$ & $\mathbf{1 0 0}$ & $\mathbf{1 5 7 4 . 1 3}$ & $\mathbf{1 0 0}$ & $\mathbf{4 8 7 . 9 6}$ & $\mathbf{1 0 0}$ & \\
\hline
\end{tabular}




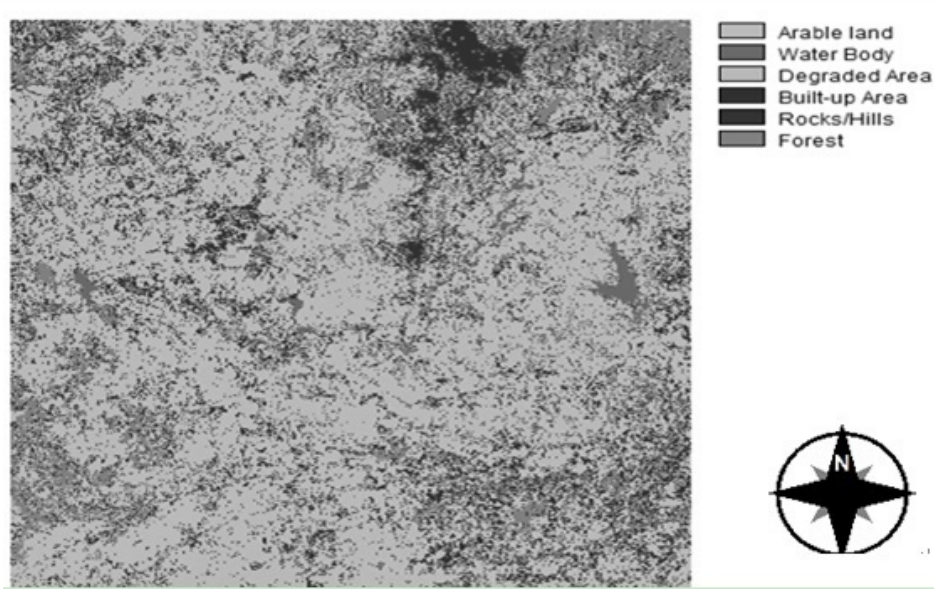

Figure 5. The landuse pattern and the extent of Mining Degradation from LandSat ETM+ 2005

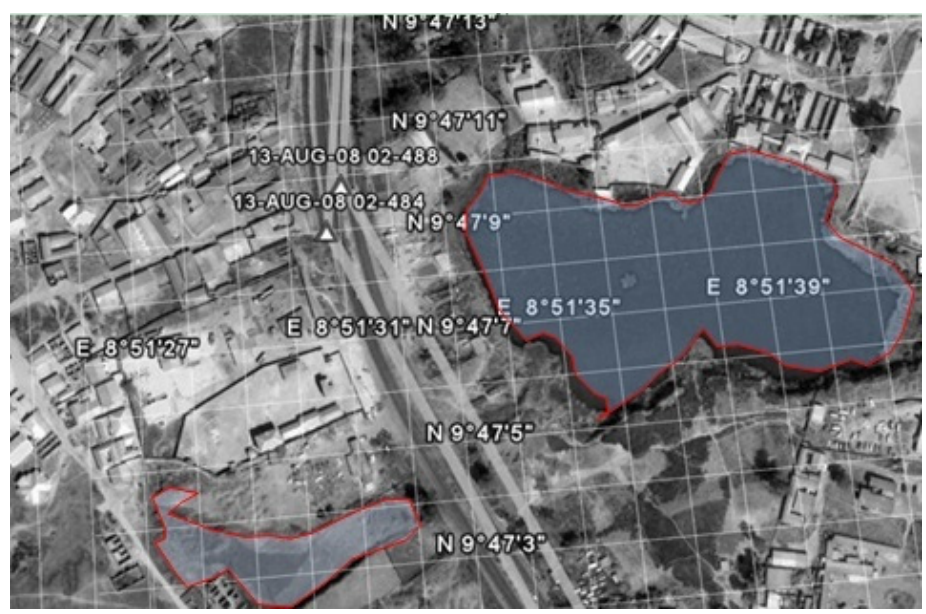

Plate 2. Encroaching derelict mining pond on the adjourning buildings and road

\subsection{Overall Consequence and Magnitude of the Landuse/Landcover Change: 1975 - 2005}

The pattern of land use/ land cover distribution in the study area for 30 years intensive mining between 1975, (pre-state creation) and 2005, reveals substantial changes both positive and negative in terms of aerial extent and percentage coverage. The overall magnitude of changes presented in Table 5 shows that out of the total size of the study area (1574.13sq.km) degraded area/land, Built-up area, and water bodies increased by $24.58 \%, 18.51 \%$ and $7.57 \%$ respectively. Whereas Arable land (farm and grazing land) decreased by $106.60 \mathrm{sq} . \mathrm{km}(14.16 \%)$, and forest reserve decreased by $264.89 \mathrm{sq} . \mathrm{km}$ to a loss of $35.18 \%$.

Table 5. Overall magnitude of change in land use/land cover, between 1975 and 2005

\begin{tabular}{|c|c|c|c|c|c|}
\hline Land use Class & $\begin{array}{c}1975 \text { Area } \\
\text { ( Sq.km) }\end{array}$ & $\begin{array}{c}2005 \text { Area } \\
\text { (Sq.km) }\end{array}$ & $\begin{array}{c}\text { Magnitude } \\
\text { of change } \\
\text { ( Sq.km) }\end{array}$ & $\begin{array}{c}\text { Percentage } \\
\%\end{array}$ & Remarks \\
\hline Arable land & 779.64 & 673.04 & 106.60 & 14.16 & Loss \\
\hline Water Body & 31.52 & 88.59 & 57.07 & 7.57 & Gain \\
\hline Degraded Area & 213.72 & 398.8 & 185.08 & 24.58 & Gain \\
\hline Built-up Area & 99.35 & 228.69 & 139.34 & 18.51 & Gain \\
\hline Rocks/Hills & 29.38 & 29.38 & 00.00 & 00.00 & NA \\
\hline Forest & 420.52 & 155.63 & 264.89 & 35.18 & Loss \\
\hline Total & 1574.13 & 1574.13 & 752.98 & 100 & \\
\hline
\end{tabular}


One of the immediate impacts of the tin mining is the destruction of the arable land and forest which results in shortage of fuelwood and construction materials for the community. This condition forces farmers not only to travel very long distances to collect wood, but also to increasingly burn crop residues and organic manure for cooking and heating. The latter has grave consequences for the fertility and productivity of the cropland as the action leads to depletion of the organic matter in the cultivated soils. The reduced possibility for cropland-expansion and severe shortage of land has also its own impact. The shortage of land has compelled farmers to practice continuous cropping and completely abandon even seasonal fallowing. Field observation and discussions with farmers suggest that cropping intensity in Bukuru has been raised to almost 100 per cent. Such continuous cultivation in a situation where little organic matter returns to the soils leads to severe soil erosion and land degradation.

\section{Conclusion}

The impact of tin mining has greatly affected the natural ecology of the study area Bukuru. Micro and macro organisms and plants have been stripped off their natural habitat due to tin mining activities. The removal of organic rich surface soils required for agricultural and human settlement results in change in landuse.

The absence of natural vegetation has greatly increased the menace of gully erosion in mining areas. Man has contributed to this cause by clearing the vegetation for firewood and agricultural practices therefore leaving the land bare by making it susceptible to erosion. Also, the overstocking of pasture results in overgrazing and removal of vegetation cover with the trail of footpaths of animals invariably become channels of erosion.

\section{Recommendations}

Results of the study show that mining activities have significant effects on the environment, especially in Bukuru area. These effects have not seriously taken into consideration for possible solution. Base on this, the following recommendations were made:

1. The distribution and expansion of mining sites should be monitored, their environmental damages should be determined; mitigation studies against these damages should be performed, and regular inspections should be executed to keep these activities under control.

2. Modern technologies should be used to obtain more effective results from these studies. Although monitoring the changes in large areas by using conventional method is very difficult, remote sensing is the most convenient technique to collect a large amount of data for this kind of areas. With the ability of satellite data, it is possible to detect and analyze the magnitude and spatial changes of natural environment which is significant for resource managers.

3. Additionally, GIS technique should be adopted and used to summarize changes in the spatial distribution of landuse/land cover classes by overlaying map of different dates and analyze their spatial coincidence to help in decision making process in order to project future land development for the study area and reduce the possible environmental problems.

\section{References}

Adepetu, A. A. (1985). Farmers and their farms on four Fadamas on the Jos Plateau (Nigeria). Environmental Resources Development Programme (J. PERDP) Interim Report. Jos Plateau.

Adepetu, A. A. (1986). Agricultural Practice and Adjustments in the Tin mining region of the Jos Plateau. The Geographical Journal, 160(76).

Adiuku-Brown, M. E., \& Ogezi, A. E. (1991). Heavy Metal Pollution from Mining practices: A case study of Zurak. Journal of Mining and Geology, 8(1), 71-77.

Ajaegbu, H. I. (1985). Rural Planning and development Prospects in a Tin mining environment. The Jos Plateau Region of Nigeria. Proceedings of the I.G.U. Commission on Rural Development Neuchated, swit-zerland, July/August.

Alexander, M. J. (1985). Historical Introduction to the Reclamation of Mine Land on the Jos Plateau. Jos Plateau Environmental Resources Development Programme. Interim Report No.4. Department of geography, University of Durham, U.K.

Houghton, R. (1994). The worldwide extent of land use change. BioScience, 44(5), 305-313.

Lillesand, T., \& Kiefer, R. ( 2000). Remote Sensing and Image Interpretation. New York: Wiley.

Musa H. D. (2010). Customary Land Tenure towards Urban Land Development in Minna. Journal of Geography, Environment and Planning, 6(2), 9-20. 
Sumaila FAG. (1989). Accessibility and Rural Development, Relationships in the Tin Mining Region of the Jos Plateau. Main Report, Published by Authority, 9(2), $11^{\text {th }}$ November. Jos: Government Printer.Pp.31.

Sumaila S. (1993). Religion, Ethnicity and the 1991 Census, in Census News, cited in House Magazine of the National Population Commission, May 1991, 2/1.

Wood, E., Tappan, G., Lietzow, R., \& Albright, T. (1998). The impact of agricultural production systems on land use/land cover change: Senegal, West Africa. Raytheon Center for Global Change, 5(2), 2-16. 